\title{
Peer Teaching and Learner-Generated Materials: Introducing Students to New Roles
}

\author{
Paul Mennim \\ Aoyama Gakuin University, Tokyo, Japan
}

\begin{abstract}
This paper reports on a classroom teaching project in which Japanese university students were asked to produce and teach a thirty-minute lesson in English based around a research topic of their own choice. It explores the feasibility of making students responsible for creating teaching materials and describes the scaffolded assistance given to the students to train them into the role of teacher. The paper reports on the participants' positive reactions to the teaching project, as reflected in questionnaire responses, and presents examples of student-generated teaching materials.
\end{abstract}

Learner-centered curricula allow students to make decisions about the content of their courses and how those courses are taught (Nunan, 1988). The project that is the subject of this paper took place in a course where students were given the responsibility to design and teach their own English language materials. Students created their goals and objectives, a level of learnercenteredness that Nunan (1995, p. 138) rated as relatively high on a scale of implementation. Scharle and Szabó, discussing learner autonomy, pointed out the benefits of granting learners a high degree of independence: "For one, learners can only assume responsibility for their own learning if they have some control over the learning process. For another, increasing independence may evoke and reinforce responsible and autonomous attitudes" (2000, p. 80). Even so, Scharle and Szabó (2000) and Nunan (1995) cautioned that learner independence does not come automatically and that learners need training and guidance to adapt to new classroom roles.

\section{The Context of the Study}

\section{Literature Review}

Such caution is relevant in the Japanese context. High schools in particular still feel pressure to prepare students for Japan's notoriously demanding university entrance exams; because these exams do not test oral communication skills, the wash-back effect means that most classes are teacher-fronted, concentrating on the written language and the deductive teaching of grammar (Sakui, 2004). Learners in such a system have little experience in taking charge of their own learning. When they reach the tertiary level, however, they may gain some experience, since, as

Language Education in Asia, 2012, 3(2), 230-242. http://dx.doi.org/10.5746/LEiA/12/V3/I2/A11/Mennim 
Hadley (1999) pointed out, Japanese universities enjoy more freedom to implement innovative courses and curricula that address the communicative deficit in high schools.

The peer-teaching project in this study took place at a private Japanese university within a general, obligatory oral English course. The aim of the course was the development of fluency and experience in a range of oral communication styles. Although the participants were first-year law majors, this course did not focus on legal English (a legal English course can be taken as an elective) but on general conversational English; it dealt with a wide range of contemporary topics. A major course component required students to contribute their own classroom content through a research project. They investigated a topic of their choice and reported the results to the class in English.

In the first semester, the report stage was an oral presentation in which students gave a largely scripted speech and responded to questions afterward. In the second semester, the report stage was a lesson, with content-based questions, devised and taught by the students. To introduce the rationale behind the teaching project, a brief discussion of L2 oral presentations follows.

\section{Advantages and Disadvantages of L2 Oral Presentations}

Oral presentations give students an opportunity to use the L2 for communicative purposes and to find ways to present relevant and easily understandable information (Legutke \& Thomas, 1991). Researching the content of the presentations also promotes critical thinking and gives students collaboration experience (Morita, 2000).

However, McCafferty and Ford (2000) pointed out that there are disadvantages associated with presentations as well, e.g., passive listening from audience members, a focus on correctness by speakers, memorization, and non-communicativeness. Some teachers might not view all of these features as negative (particularly a focus on correctness) but may still share McCafferty and Ford's concern that classroom presentations can become stale and thus not reach their full potential as a communicative event. Yang (2010), for example, reports from her study of Chinese students in Canada that "in giving oral presentations, ESL students, especially those less fluent in English, tended to restrict the extemporaneous elements in their speeches and speak from their memory of a written text" (2010, p. 14).

Legutke and Thomas (1991) stress the importance of overcoming these shortcomings and suggest that when a presentation becomes a "tedious verbatim account" (p. 276) that leaves the audience inattentive, then knowledge is not shared and the information gathered essentially becomes useless. To avoid this outcome, they suggest encouraging students to adopt new classroom roles and utilize skills more usually associated with the teacher, including preparation of support material, task design, and even the management of skill training. This suggests a classroom event rather different from the oral presentations familiar to most teachers. Instead, a report stage where students devise content to teach their research topic might be imagined.

\section{The Concept of Students as Teachers}

At first glance, transforming students into teachers may seem challenging. However, the literature, briefly sampled here, demonstrates that encouraging students to take on teacher roles and make contributions to L2 lessons is an already well-established trend. 
In an activity that might be viewed as an initial stage in the transfer of classroom roles, Marcus (2010) describes a "student generated approach" to vocabulary teaching in an advanced university ESL program in California. The teacher simply asked students to bring in examples of vocabulary noticed in their daily lives and then wrote each new word on the board, explained its meaning and highlighted other aspects, e.g., common collocations and pragmatic associations. While the students were not asked to teach, they were still given some responsibility for selecting lesson content.

Altschuler (2001) described a speaking activity used in Taiwan in which students took on a teacher role in a larger sense. In his "Ask the Expert" activity, the teacher assigned topics for individual students to research as a homework task (e.g., to find out about tourist activities in a certain country). In the next class, students demonstrated their new status as experts in the topic by fielding questions from their peers, sharing knowledge orally in a question-and-answer session. Altschuler suggested this activity promotes the message that learners need not rely on the teacher as the sole repository of knowledge, since they all "briefly act as teacher . . . and observe one another doing so" (p. 32). He also suggested that the knowledge and experience the students gain as independent researchers results in more confident speech compared to traditional oral presentations.

Two earlier examples also describe a more developed student-as-teacher approach. Villani (1995) described how a class of EFL learners in Italy, aged 12-13, was asked to create a language exercise workbook. Trawling through their school textbooks, the students decided which types of exercise were most appealing or useful and re-employed the formats to make original questions. The resulting workbooks consisted of form-focused language exercises and were assigned to a younger class (aged 11-12) as summer vacation homework. In a context more similar to that of this article, Assinder (1991) reported that in a preparatory course at an Australian university, EFL students prepared teaching materials to accompany short television news broadcasts. After a few weeks, the teacher asked the students to create teaching materials. Using a set of videos, they then used the lesson format introduced by the teacher to create comprehension questions, highlight problem vocabulary, and prompt discussion on the content.

The studies above show how learners can enter into the role of teacher in different ways. The learners' contribution could be relatively small or their performance relatively short. They did not all have to teach the materials they produced. In the latter two studies, the students' production of materials was made easier through familiarity; they replicated a format that they had worked on as learners and therefore had a clear model in mind. In the project described in this article, the idea of familiarity was also built in through a process of scaffolded assistance, including task modeling and practice sessions. However, the project differed from the above studies in that it gave students even more freedom to innovate. Although students were presented with a template, they were free to depart from it and create their own exercises; further, they were free to choose any topic.

\section{The Teaching Project}

The aim of the project was to investigate the feasibility of giving students the novel and challenging experience of taking up a teacher role in producing and teaching a relatively long interactive lesson that explained a topic to the class. It was hoped that this project would have similar 
advantages to those reported in the previous studies, i.e., increased motivation and confidence, real communication, and increased student responsibility for their own learning.

The oral English course meets once per week throughout the academic year. The teaching project took place in three sections; each section had around 22 students whose English proficiency lay generally between higher intermediate and advanced. The project lasted approximately seven weeks in the second semester and comprised three phases:

- Phase 1 - Teacher-produced, teacher-taught lessons: one 90-minute class

- Phase 2 - Teacher-produced, student-taught lessons: three 90-minute classes

- Phase 3 - Student-produced, student-taught lessons: three 90-minute classes

\section{Phase 1: Teacher-Produced, Teacher-Taught Lessons}

Lesson format. Interactivity was built into the format. First, the lessons were to be team produced and team taught by groups of three, so collaboration was an essential element in creating the lessons. Second, the students in the audience were also put into groups of three at the beginning of the lesson. They completed all of the lesson exercises together, providing opportunities for discussion and collaboration.

The author produced 30-minute sample lessons. Each lesson was based around a general topic (e.g., crime, health, environmental issues) and included various tasks and exercises selected to introduce content, highlight useful linguistic features, and generate discussion. A 30-minute lesson was judged to be long enough to convey an appropriate amount of content and let each member of the teaching group take charge of one lesson segment.

The sample lessons were based around a handout and generally began with a paragraph that introduced the topic and doubled as a cloze exercise for vocabulary relevant to the topic. Each lesson handout contained group discussion questions to elicit audience opinions and experiences of the topic. Because the purpose of the course was to give students speaking practice, a group discussion was the only obligatory element for the lessons.

Exercise types in the sample lessons included:

- Convergent judgment tasks: Requiring interaction aimed at achieving a consensus, these tasks are considered effective in encouraging negotiation of language form, since a good level of understanding is necessary to reach agreement (Nation \& Newton, 2009). For example, groups were asked to agree on appropriate punishments for various crimes or to identify the most serious examples from a list of stress symptoms.

- Interviews: Interviews between groups let members see how another group had responded to the lesson questions. For example, groups interviewed each other to exchange opinions or to confirm answers regarding the questions in the lesson.

- Language-based exercises: These were designed to teach vocabulary relevant to the lesson topic. For example, students translated key vocabulary into Japanese or identified items of English vocabulary that could appropriately describe a photograph. 
- Quiz questions: Short questions based on information pertaining to the topic were used.

The teaching process. As well as familiarizing students with the kind of lesson they would be expected to produce, the sample lessons focused student attention on decisions they would have to make as teachers in areas such as classroom management and timekeeping. During Phase 1, the students were given a worksheet to identify phrases the teacher used to perform various functions. A worksheet question is shown in Figure 1.

\begin{tabular}{|ll|}
\hline What does the teacher say. . . & to make groups of three? \\
& to begin the lesson? \\
& to ask a student to read something? \\
& to move on to the next section? \\
\hline
\end{tabular}

Figure 1. Example question from a worksheet on identifying teacher phrases for classroom management.

This phase included two sample lessons and was completed during one 90-minute class. At the end of each teacher-taught lesson, the phrases were discussed in a plenary session. Students remarked that although they had often heard the teacher say these phrases and readily understood them, it was difficult to accurately reproduce the phrases. This activity therefore helped to raise awareness of active use versus passive understanding of functions and forms such as instructions, questions, and imperatives.

\section{Phase 2: Teacher-Produced, Student-Taught Lessons}

In this rehearsal phase, each group taught a 30-minute teacher-produced lesson. This phase took three weeks, as there were two sample lessons per class. One week before teaching their lesson, students received the lesson handout and teacher's notes, including an answer key, a review of the teaching expressions, and other directions (e.g., items to write on the blackboard or alternative ways to conduct the same segment). A sample of these notes for a lesson on fair trade is provided in Appendix A. After each student-taught lesson, there was a short plenary session of around 5 to 10 minutes to discuss issues that had arisen.

The plenary sessions began with the teacher addressing problems and critiquing aspects of each group's performance. For example, the teacher remarked that the original list of teaching phrases had omitted some useful phrases, as some students had struggled with the correct wording for instructions such as "please turn the page" or "please try to finish soon." The teacher also pointed out the reluctance of some student-teachers to check that everyone had understood their instructions and the tendency for student-teachers to call exclusively on students of their own gender.

The teacher then called on the student-teachers to comment on aspects of their performance that they were proud of or that they would change. Some student-teachers cited time management as a problem; on occasion, too much time (or not enough) was allocated to individual exercises. However, the student-teachers were sometimes adept at time management even at their first attempt in Phase 2. Some, for example, imposed time limits to complete the various sections, while others exercised their judgment and instructed the class simply to skip a section if the lesson was going overtime. Additionally, some student-teachers remarked that they had adapted and supplemented the sample lessons unprompted, including, for example, their own introductions and 
conclusions to the lesson, often in the form of a topic-related personal anecdote. Others had completed extra research on the topic and introduced new information. In these ways, Phase 2 helped to smooth out unexpected problems and showcase strategies that other groups could adopt when teaching. The teacher stressed positive points to the class and advised them in the design and teaching of their own lessons in Phase 3.

\section{Phase 3: Student-Produced, Student-Taught Lessons}

In Phase 3, the students produced and taught their own lessons. They had formed groups at the beginning of Phase 2 and had about three weeks to prepare their lesson. In this phase, three weeks were required for six groups to teach a lesson. Each 90-minute class had two lessons, including extra time for preparation, e.g., distributing handouts and writing introductory information on the blackboard. The lessons ran for the required amount of time, and the students performed their various teacher duties efficiently. As in Phase 2, they were able to make adjustments for effective timekeeping. They gave clear instructions and controlled classroom discourse, calling on individual students for answers and checking on the audience's progress. They did this by making frequent use of the phrases studied in Phase 1.

In general, the lessons went smoothly and included a variety of exercises for the audience to complete. The students chose a wide variety of topics, including ones related to business, science, technology, and culture. There were 21 lessons from the three sections. Six example exercises are presented in Appendix C.

\section{Students' Evaluation of the Teaching Project}

In the final week of the second semester, the students in the three classes were given a short openended questionnaire inviting comments on the two main communication tasks they had completed over the year: "Which did you prefer as a final task for the semester: giving a presentation or teaching a lesson? Why?"

The responses to the first part are shown in Table 1. A clear majority stated a preference for lessons as a final semester task.

Table 1

Student Preferences

\begin{tabular}{|l|c|c|}
\hline & As teacher or presenter & As audience member \\
\hline Lessons & $36(70 \%)$ & $35(67 \%)$ \\
\hline Presentations & $16(30 \%)$ & $15(29 \%)$ \\
\hline No preference & 0 & $2(4 \%)$ \\
\hline Total & 52 & 52 \\
\hline
\end{tabular}

The second part elicited reasons for their preference (see Table 2). There was a wide range of responses, the majority of which are gathered together here in five general categories, along with the number of comments representative of these categories. Comments illustrating these points are shown in Appendix B. 


\section{Table 2}

Reasons for Preferences

\begin{tabular}{|c|l|c|}
\hline & Benefit of lesson task & $\begin{array}{c}\text { Number of } \\
\text { mentions }\end{array}$ \\
\hline 1 & Communicative / interactive nature of task & 20 \\
\hline 2 & Inherent interest in task or topics & 17 \\
\hline 3 & Level of difficulty of task & 12 \\
\hline 4 & Research and intellectual engagement & 5 \\
\hline 5 & Teamwork & 4 \\
\hline
\end{tabular}

Note. $n=52$

\section{Discussion}

The students' comments about the project mention the same potential benefits attributed to oral presentations at the beginning of this paper: they used the L2 for communicative purposes, employed critical thinking in selecting and editing information to share, and gained experience in teamwork. This confirmed the author's view that the lessons were an interactive and creative way to share knowledge. The students' comments also reveal positive effects stemming from their new roles as teachers and content creators. They appreciated increased student participation and communication. Additionally, they had an inherent interest in the chosen topics and reflected on the difficulty of the task and on the processes of teaching.

The training phases were important in introducing the students to their new teaching roles. The awareness-raising exercises and plenary sessions accompanying the sample lessons helped students to appropriate the linguistic means to run their lessons and to consider elements of classroom management. The sample lessons provided a template for the production of classroom materials. The students replicated cloze tests, discussion questions, and language-based exercises. Those cautious of their new role of producers of classroom content adhered closely to the template, while more confident students made innovations, as was observed with a group that used audio content (see Appendix C).

The training phases represented an investment in teacher time. There were six or seven groups in each class, which meant creating nine sample lessons (two for Phase 1 and seven for Phase 2) so that each group had a practice lesson. However, these 30-minute lessons were not long, typically containing four or five short exercises. In the author's case, using the same sample lessons for three separate sections helped justify this investment.

Although a clear preference for the teaching task was expressed in the questionnaires, the students' responses should not be considered a rejection of oral presentations. Nearly $30 \%$ of the students preferred oral presentations, described by some students as a valuable real-world task. Therefore, the teaching task is not a replacement for presentations but rather a worthwhile addition to any teacher's oral English syllabus. The aim of this particular course was to provide practice in a range of styles of communication; the inclusion of different ways of presenting information complemented that objective. 


\section{Conclusion}

The teaching project helped to gradually introduce students to their new teaching roles and provided guidance in materials production and basic classroom management. The students successfully accomplished their teaching task by devising creative and informative materials to report their research. They made a good effort to know the necessary facts to teach their topics and develop a good command of language to direct the class. The process resulted in classes with a busy atmosphere and lesson content keenly anticipated by the audience, who knew they would be asked to engage with the topic. This project suggests the feasibility and value of giving students the chance to produce and teach their own classroom content.

\section{Author Note}

Paul Mennim, Faculty of Law, Aoyama Gakuin University, Tokyo, Japan.

Correspondence concerning this article should be addressed to Paul Mennim, Faculty of Law, Aoyama Gakuin University, Tokyo, Japan. E-mail: mennim@hotmail.com 


\section{References}

Altschuler, L. (2001). "Ask the Expert": Oral presentations that work. TESOL Journal, 10(4), 31-32. Assinder, W. (1991). Peer teaching, peer learning: one model? ELT Journal, 45(3), 218-229. http://dx.doi.org/10.1093/elt/45.3.218

Hadley, G. (1999). Innovative curricula in tertiary ELT: A Japanese case study. ELT Journal, 53(2), 92-99. http://dx.doi.org/10.1093/elt/53.2.92

Legutke, M., \& Thomas, H. (1991). Process and experience in the language classroom. New York, NY: Longman.

Marcus, S. (2010). A difference perspective on vocabulary acquisition. TESOL IEP Newsletter, 21(1).

McCafferty, E., \& Ford, K. (2000). Making student presentations interactive in the context of Japanese EFL classrooms. TESOL Journal, 9(3), 30-31.

Morita, N. (2000). Discourse socialization through oral classroom activities in a TESL graduate program. TESOL Quarterly, 34(2), 279-310. http://dx.doi.org/10.2307/3587953

Nation, I. S. P., \& Newton, J. (2009). Teaching ESL/EFL listening and speaking. New York, NY: Routledge.

Nunan, D. (1988). The learner-centred curriculum. Cambridge, England: Cambridge University Press.

Nunan, D. (1995). Closing the gap between learning and instruction. TESOL Quarterly, 29(1), 133158. http://dx.doi.org/10.2307/3587808

Sakui, K. (2004). Wearing two pairs of shoes: Language teaching in Japan. ELT Journal, 58(2), 155163. http://dx.doi.org/10.1093/elt/58.2.155

Scharle, Á., \& Szabó, A. (2000). Learner autonomy: A guide to developing learner responsibility. Cambridge, England: Cambridge University Press.

Villani, D. (1995). Summer workbook project: A purposeful way to exploit student-generated exercises. English Teaching Forum, 33(1), 33-34.

Yang, L. (2010). Doing a group presentation: Negotiations and challenges experienced by five Chinese ESL students of commerce at a Canadian university. Language Teaching Research 14(2), 141-160. http://dx.doi.org/10.1177/1362168809353872 


\section{Appendix A \\ "Fair Trade": Teacher's Notes}

Useful expressions:

Okay, let's get started. / Okay, let's begin.

Can you please read this paragraph?

Does anyone need more time?

Who would like to volunteer an answer?

Does anyone have the answer?

"Subsidy" (appearing in the introduction) is 補助金. Write this translation on the blackboard.

Answers

1. Products and countries

$$
\text { coffee }=\text { Brazil } \quad \text { cocoa }=\text { Ghana } \quad \text { sugar }=\text { Brazil } \text { tea }=\text { India } \text { bananas }=\text { India }
$$

2. Chain of events

( 5 ) The big chocolate company spends a lot of money on advertising to encourage sales.

( 2 ) The farmers sell their cocoa to a middleman for a very low price.

( 4 ) The cocoa is taken by ship to Europe where it is processed.

( 3 ) The middleman sells the cocoa to a big chocolate company in Africa.

( 1 ) Farmers in developing countries work hard to grow crops like cocoa.

3. Who gets what?

Farmers growing cocoa in Ghana

The government in Ghana in tax

Shops or Supermarkets in the UK

The UK government in tax

UK companies making chocolate
7 pence

7 pence

28 pence

17.5 pence

40 pence

4. Fair trade sales

$830,000,000=$ Eight hundred and thirty million

$1,600,000,000=$ One point six billion

5. What do you think?

Write these five statements on the board. Leave big spaces between each one - at least $50 \mathrm{~cm}$.

1. Unfair trade is unjust. We must change this situation.

2. This is really bad, but I am not sure if we can do anything.

3. I don't like what is happening, but I need cheap clothes and cheap food.

4. We need produce and local producers need jobs. They would be worse off without our trade.

5. Conditions may not be perfect now, but they may slowly improve naturally.

Ask the class to approach the board and stand beside the statement that matches their opinion. 


\section{Appendix B \\ Comments Representative of Table 2 Categories}

1. Communicative / interactive nature of task

Giving a presentation is only speaking a prepared manuscript, but teaching a lesson have communication.

I prefer lessons to presentations. Because, lessons always have some question, we can join in our class. And increase the chance that we speak English!

[I prefer] the lessons because during the presentation we audience have to do nothing but listening to the presentation.

2. Inherent interest in task or topics

I like the lessons because everyone make an interesting lesson.

Because I quite like teaching things to people.

3. Level of difficulty of task

I preferred teaching a lesson because it is very fun and easy to do.

I prefer teaching a lesson. That's because we can know how difficult it is to tell other people what we want to teach in another language.

4. Research and intellectual engagement

I prefer the teaching lesson because I can choose the topic I'm interested in and searching data on the topic is so interesting. I could learn the logical thinking.

I prefer teaching a lesson because for doing that, I had to study about my topic and make originals questions so it make me confident.

\section{Teamwork}

I prefer teaching a lesson than presentation because, in my case, presentation was made only by me, not by [co-operation]. In the other hand, teaching a lesson was made by all of our team so it was fun. 


\section{Appendix C \\ Examples of Student-Produced Exercises}

All examples show the students' own language and original errors.

1. Cloze exercise

Talking of espresso, Italy is the home of it. ( 1 ) coffee for Italian means espresso. Drip coffee popular in Japan is ( 2 ) in Italy. The word espresso means ( 3 ) because to make this coffee it takes less time for extracting thanks to the machine. The person who is a ( 4 ) operator of an espresso machine is called a 'barista'.

normal fast professional minor

This group used the cloze exercise to pass on information they gathered in research about their topic. It teaches differences in coffee culture between Japan and Italy and explains relevant items of vocabulary.

\section{Quiz question}

In a matching exercise, edited somewhat here, students were asked to draw an arrow between the Mac product and its corresponding description.

$\begin{array}{ll}\text { Apple I } & \begin{array}{l}\text { New generation of device that changed our world. It became the } \\ \text { definition of smart-phone. }\end{array} \\ \text { iPad } & \text { The first personal computer for non-business purpose. With } \\ & \text { reasonable price, it spread globally. } \\ \text { iPhone } & \text { Third category between laptop and smart phone. }\end{array}$

Again, the question allowed the group to share the information they had gathered from their research. As they revealed the correct answers, they supplemented the descriptions with a minipresentation that gave further information on each product and showed images to illustrate them. The original unedited question covered six products.

\section{Discussion question}

Do you believe in aliens? (talk about it)

Sometimes on TV, in books, or newspapers, and most on Internet, there are many of articles written about aliens, and these days, they are not taken as a joke. Speak in your group, and give us your opinions.

With this short paragraph, the group set up a discussion on the possibility of alien life. The wording of their instructions shows some sophistication in the way that it addresses the potential trivial nature of the topic and requests the students to take the discussion seriously. 
4. Language-based question

\begin{tabular}{|c|c|c|c|}
\hline 時は金なり & ( & ) is ( & ) \\
\hline $\begin{array}{l}\text { 愛は盲目 } \\
\text { ai wa moumoku }\end{array}$ & ( & ) is ( & ) \\
\hline $\begin{array}{l}\text { どしゃぶりの雨が降る } \\
\text { doshaburi no ame ga furu }\end{array}$ & It rains & & ) and ( \\
\hline
\end{tabular}

The group had researched idioms and proverbs in English and asked the class to translate Japanese examples with close English equivalents. The first two take direct translations (time is money; love is blind). Although the third example (raining cats and dogs) does not translate literally, the Japanese translation still expresses the meaning of heavy rain.

\section{Audio-based question}

While all of the Phase 1 and 2 sample lessons were text-based, this Phase 3 example included audio content by connecting a smartphone to a portable speaker. The class listened to part of a Beatles track and completed the printed lyrics.

Listen to the music and fill in the blank spaces.

I'd like to be under the ( ) In the ( )'s garden in the shade.

6. Convergent judgment task

A group teaching on the topic of aphorisms or famous sayings (an example they gave was President Barack Obama's "Yes We Can" campaign slogan) asked the students to think of their own examples and agree on which one was the wittiest. 